\title{
Combating rural poverty through altruism: a model for sustainable education
}

\author{
Jeffrey Overall \\ School of Business, \\ Nipissing University, Canada \\ Email: jeffreyo@nipissingu.ca
}

\begin{abstract}
Nepal, one of the poorest nations, is plagued with high illiteracy rates and child labour. The children that enter the workforce, namely from rural areas, experience inhumane conditions and many enter the human trafficking trade. With a reach of over 100 million people and $68 \%$ of beneficiaries crossing the poverty line, micro-financing has proven to be an effective tool at addressing rural poverty. However, there are disadvantages hidden in these statistics, namely usurious interest rates, high enterprise failure rates, and aggressive repayment schemes that cannot only perpetuate impoverished conditions, but can also contribute to them. To address the disadvantages of micro-financing, a model for sustainable education is developed in this paper using altruism theory and the banking monetary multiplier. Through this model: 1) the cycle of poverty can be reduced; 2) literacy rates can be increased; 3) the supply of children that are trafficked abroad can be minimised.
\end{abstract}

Keywords: altruism; child labour; human trafficking; micro-financing; Nepal; non-profit; rural poverty; social entrepreneurship; sustainable development; sustainable education.

Reference to this paper should be made as follows: Overall, J. (2017) 'Combating rural poverty through altruism: a model for sustainable education', World Review of Entrepreneurship, Management and Sustainable Development, Vol. 13, No. 1, pp.69-83.

Biographical notes: Jeffrey Overall is an Assistant Professor at the Nipissing University, School of Business. Prior to this, he was an Assistant Professor at the Ted Rogers School of Management at Ryerson University in the Entrepreneurship and Strategy Department. He completed his PhD at the University of Bradford, School of Management in the UK. He conducts research in the fields of business ethics, corporate social responsibility, strategy, and entrepreneurship.

\section{Introduction}

Nepal is a landlocked nation nestled between two giants - India and China. Though sandwiched between two soaring economies, the economic situation in Nepal is anything but promising. In fact, the economic prospects are bleak. Nepal is one of the poorest nations with soaring illiteracy rates and the second highest level of child labour (Chakrabarty et al., 2011; Dana, 2014). As a result of poverty, polygamy, and gender discrimination (Baker and Hinton, 2001), Nepalese children are forced into the labour 
market, prematurely. Over 2 million Nepalese children under the age of 14 are actively engaged in the workforce (Chakrabarty et al., 2011). Through their exposure to child labour, these children, namely from rural areas, experience inhumane working conditions and many are trafficked into the sex trade. In fact, nearly 12,000 Nepalese children enter this horrendous industry each year (Baker and Hinton, 2001; Gilligan, 2003).

To address poverty in the rural areas of underdeveloped nations, micro-financing, which involves lending low-value collateral-free short-term loans to groups of impoverished entrepreneurs, is often used. With a reach of over 100 million people (Rajouria, 2008), repayment rates of $98 \%$, and $68 \%$ of beneficiaries crossing the poverty line (Yunus et al., 2010), micro-financing has proven to be an effective tool at addressing rural poverty (Shakya and Rankin, 2008). The advantages of micro-financing have been advocated by world-renowned economists and Nobel Laureates, such as Amartya Sen (1999), and international organisations like the United Nations. Although there are many advantages to micro-financing, the disadvantages, namely high interest rates and aggressive repayment schemes, have been well-documented (e.g., Hassan, 2002; Rajouria, 2008). As a result of these issues, micro-financing might not be the most effective tool to reduce poverty. In certain situations, micro-financing might actually contribute to it and, in the extreme, perpetuate it. Importantly, micro-financing should not be considered the only tool to address rural poverty. Alternative models should be considered.

In this paper, using altruism theory and the banking monetary multiplier, I develop a model for sustainable education that can address the disadvantages of micro-financing. This research contributes to the literature in three important areas. First, the model can help with reducing the cycle of poverty. Second, the model for sustainable education can assist with increasing literacy rates in underdeveloped nations. Third, the model can minimise the supply of children that not only enter the workforce prematurely, but it can also reduce the number of children that enter the human trafficking industry. In the first section of this paper, I provide a brief background of rural poverty in the Nepalese context. I then show how rural poverty has been addressed with a focus on micro-financing. In the second section, I discuss altruism theory. In the third section, the model for sustainable education is presented using a case example of an organisation operating under the framework. In the final section, implications for practice and future directions are discussed.

\section{Background}

Prior to 2008, Nepal, the birthplace of Buddha, was a kingdom for 240 years (Dana, 2014). Culturally, the country boasts two religions, Buddhism and Hinduism, which are worshipped by two main groups - the Tibeto-Burman Mongoloids and the Indo-Aryans (Dana, 2014). Although now illegal, the social structure of Nepal continues to be influenced by the caste system. In Nepal, society is segregated into five main hierarchical structures, or castes, which influence all aspects of life, namely marriage, employment, education, and interactions in the community. The highest caste in the hierarchy is the Brahmins (priests), followed by the Kshtriya (warriors), Vaishya (traders), Shudras (artisans), and the Harijans (untouchables). The untouchables maintain the lowest group in the hierarchy and are heavily discriminated against in society (Gill et al., 2011) and, as a result, are often the most impoverished. 
Through its rich culture, Nepal attracts thousands of tourists and pilgrims to its borders annually. Although a picturesque Himalayan country with an inspiring culture, Nepal is one of the poorest nations with many sociological problems, such as: poverty, pollution, deforestation, and overpopulation (Dana, 2014). Poverty in Nepal appears to be unrelenting. The per capita GDP is $\$ 1,200$ USD with $25 \%$ of the population living below the poverty line. A contributor to the poor economic prospects in the nation is a direct result of the low literacy rates. In fact, $66 \%$ of men and $90 \%$ of women cannot read (Dana, 2014). The highest levels of poverty and, by extension, illiteracy rates, are within the rural areas, which are scattered through the hills and valleys of the Himalayan Range. In these areas, Nepalese children are often required to assist in expanding the household income by abandoning their education and entering the workforce (Baker and Hinton, 2001). However, the child labour wages are minimal to non-existent and insufficient to remove a family from poverty (Gilligan, 2003). The relinquishment of education for employment causes the Nepalese illiteracy rates to soar, which transfers poverty from one generation to the next (Chakrabarty et al., 2011).

Child labour is disconcerting to the international community and action has been taken to minimise its occurrence. Although the United Nations has developed projects to address the child labour rates in Nepal (Gilligan, 2003), the severe poverty causes child labour rates to perpetuate. Perhaps most alarming is the large number of Nepalese children that are trafficked into the sex trade. To address this inhumanity, the United Nations has established mandates to reduce human trafficking, but without reducing poverty, which is a significant antecedent to children entering this horrendous market (Wheaton et al., 2010), the supply of children will likely continue. Indeed, an innovative solution to this diabolical problem is needed.

\subsection{Entrepreneurship in Nepal}

One method of reducing poverty involves the promotion of entrepreneurship. Although there are conflicting views on the definition of entrepreneurship (Ahmed and McQuaid, 2005), entrepreneurship has been argued to involve creating new marketplaces to meet evolving customer demand through innovation (Schumpeter, 1942). Like most nations, the Nepalese government is aware of the importance of entrepreneurship in developing the national economy. To this end, several policies have been implemented to shift the economy away from its reliance on agriculture and to stimulate entrepreneurship throughout the country (Dana, 2014). Specifically, the government has implemented policies on two fronts:

1 foreign direct investment (FDI), which involves reducing the barriers to entry within its markets, decreasing regulations, bureaucracy, and corruption (Dana, 2014)

2 promoting entrepreneurship among Nepalese citizens.

According to the latter, the government has developed a small business promotion project, which is used to improve training for entrepreneurs that can hopefully curb poverty (Dana, 2014). However, it is difficult for the rural Nepalese to gain access to these programmes because, as a result of their location, they are alienated from the rest of Nepal. To address this issue, programmes that target rural entrepreneurs, involving vocational training and education, have been implemented (Dana, 2014). Beyond this, the Agricultural Development Bank of Nepal provides loans to entrepreneurs that possess 
collateral (Dana, 2014). However, many Nepalese entrepreneurs, or budding entrepreneurs, are heavily impoverished and do not have collateral, which prevents them from accessing much needed credit. As a result of this lack of credit, many of the rural poor are unable to lift themselves out-of-poverty (Sica and Testa, 2009), which not only causes the cycle of poverty to continue, but also contributes to the psychology of poverty. In this way, the rural poor accept their impoverished state and believe that there is no hope for improvement in that poverty becomes their fate (Ang, 2004).

Although steps have been taken to stimulate entrepreneurship, the nation is beleaguered by not only poor telecommunication and hydroelectric infrastructures (with power outages lasting more than 12 hours per day), but also a horrendous transportation infrastructure. Indeed, distribution has proven to be a challenge for many organisations as Nepal boasts one of the highest elevations in the world with limited road access (Dana, 2014). The existing roads are typically unsealed mountain roads and, as a result, organisations often need to use small trucking fleets, which add both cost and time to distribution (Walley, 2004).

Beyond this, Nepal remains plagued by corruption and inadequate awareness of the benefits of entrepreneurship (Dana, 2014). The latter is the result of the caste system in that entrepreneurship is often not considered an appropriate career option. In fact, it is has been argued that the caste system has severely inhibited the development of entrepreneurship and, by extension, the Nepalese economy (Gill et al., 2011). Specifically, as a result of the caste system, whereby the Brahmins (priests) and Kshtriyas (warriors) are the highest castes, it is unattractive for these members to start their own businesses as entrepreneurship is typically reserved for members of the lower castes (Dana, 1995; Light and Dana, 2013). Put differently, entrepreneurship is against the norms of various groups in this society. Perhaps most unfortunate is that in these societies, when entrepreneurs develop their own enterprises, they lack the needed social capital, networks, and access to funding that are vital to entrepreneurial success (Light and Dana, 2013). To access funding, many would-be entrepreneurs are forced to access credit through criminal loan sharks whereby they pay exuberant interest rates (Ang, 2004). As a result, many falter (Tata and Prasad, 2008).

\subsection{Social entrepreneurship through micro-financing}

Although there are many advantages to globalisation to economies such as Nepal, including accelerated growth attributed to FDI, there are significant disadvantages that impact the most destitute people in Nepal - the rural poor. Bhensdadia and Dana (2004) contended that the rural poor are often left out of economic advancement as they do not have access to the knowledge, capital, and assets needed to flourish in the global economy. As a result, these members of society have not had the opportunity to reach their full economic potential (Deb, 2013). To address this social need, entrepreneurs with social motivations have attempted to use their innovative tendencies to solve social problems.

In a social context, entrepreneurship is often needed to address the evolving needs of society through the development of social enterprises. Holloway (2010, p.9) argues that social enterprises are "born from a reforming zeal which dislikes the status quo, and wants to improve things... by changing the ways that development is carried out and by initiating a better way of doing things". In other words, social entrepreneurs are distinct in that they have social visions associated with their ventures and use this, in combination 
with their resourcefulness, to solve social problems (Meewella and Sandhu, 2012). As a result of their innovative predispositions, social entrepreneurs not only address social needs, but also, create economic value (Agrawal and Gugnani, 2014; Rexhepi et al., 2013).

To alleviate poverty in rural Bangladesh, micro-financing was developed by a social entrepreneur, Muhammad Yunus, through the Grameen Bank. The Grameen Bank (established in 1974 in Bangladesh) was founded on the principle of providing the rural poor with micro-financing loans. Micro-financing loans are collateral-free and expected to be invested in micro-enterprises (Rajouria, 2008). Micro-financing is based on the theory that by accessing credit, entrepreneurs will be able to develop micro-enterprises and, subsequently, remove themselves from poverty by becoming self-sufficient (Fujita, 2000; Karim, 2008). Through this model, loans are typically given to groups of five rural entrepreneurs that are used to start income-generating businesses (Sankaran, 2005), which often involve vending stands, tailoring, weaving, and small food services (Tata and Prasad, 2008).

In the traditional micro-financing model, entrepreneurs are encouraged to form groups with people that they know and trust (Kobeissi and Damanpour, 2003). When the group is formed, members set schedules whereby they agree on where to meet, the frequency of their meetings, and the agenda (Sankaran, 2005). In the early stages of group formation, the groups are typically observed and audited by employees of the micro-financing institution (MFI), which can ensure that the group members are conforming to the policies of the MFI (Kobeissi and Damanpour, 2003). These group members are responsible for repayment and, if a member defaults on their micro-loan, the other group members cannot access additional credit until the outstanding debt is repaid (Rajouria, 2008). Through this model, the Grameen Bank has been successful in collecting payments and providing relief to over three million impoverished members of society through over 1,000 branches whilst remaining profitable (Seelos and Mair, 2005). Throughout many impoverished nations, micro-financing has proven to be a useful tool in not only alleviating poverty and exploitation (Ang, 2004), but also enabling the impoverished to participate in the economic and political environments of our global society (Bharti, 2014; Sankaran, 2005). The 2006 Nobel Peace Prize awarded to Muhammad Yunus and Grameen Bank underpins the success of micro-financing.

As a result of the success, the traditional model of micro-financing attributed to Grameen Bank has been replicated by many MFIs (Richardson, 2004). However, many MFIs do not follow the traditional model established by the Grameen Bank. In fact, many of these institutions charge exuberant interest rates. Considering that interest rates are unregulated in Nepal (Rajouria, 2008), many MFIs promise their shareholders returns of $15 \%$, which is achieved by charging borrowers interest rates from $25 \%$ to $45 \%$ (Hassan, 2002). Through these high-interest rates, impoverished borrowers become trapped in endless cycles of debt (Hassan, 2002), which can perpetuate their impoverished state.

Beyond the high interest rates, considering that group members are responsible for repayment and cannot access additional credit until all loans are repaid, outstanding payments cause significant hostility toward the defaulting group member (Shakya and Rankin, 2008). Defaulters can become subject to peer pressure, bullying and shaming, which can involve public ridicule (Karim, 2008). To ensure their supply of credit is not jeopardised, the other group members will attempt to repay the outstanding debt by any possible means, which often subjects the defaulting group member to peer pressure, 
public ridicule, physical abuse, and theft (Karim, 2008). In several cases, group members have entered a defaulter's residence, removed valuables such as livestock, which are often the defaulter's only source of income, and sold them to repay the outstanding debt (Shakya and Rankin, 2008). It is argued that these acts of theft and peer pressure contribute to the high repayment rates (Karmin, 2008) and leave the defaulter in a worse economic state than they were prior to receiving the loan. Importantly, in many Asian contexts, 'face' (or honour) is vital to one's social status (Su and Littlefield, 2001). If one's honour is lost through public shaming, a family could be excluded from community interactions, which would be detrimental to their functioning in society (Karim, 2008). Although MFIs provide loans without monetary collateral, non-monetary collateral is taken through the borrowers' honour (Karim, 2008). To avoid the negative social implications associated with defaulting on a loan; near defaulters seek additional credit (Rajouria, 2008) by borrowing funds from other sources (Shakya and Rankin, 2008).

Beyond the endless cycle of debt, micro-financing hinges on the theory that the rural poor are entrepreneurs and borrowers use credit to fund micro-enterprises (Yunus et al., 2010). However, the failure rates of new ventures in industrialised nations are high - often within the $75 \%$ range (Grieco and Hogarth, 2004). These ventures are often managed or founded by entrepreneurs with business training. Conversely, in the rural areas of less-developed nations, many of the recipients of micro-financing loans are illiterate with virtually no business training (Ahmad, 2012; Rajouria, 2008). They also do not possess experience with the credit system and how borrowers need to repay their loans on-time (Ahmad, 2012). Due to a lack of formal training, the failure rates of micro-enterprises can be significantly higher. However, the failure rates of these enterprises are often concealed in the high repayment rates associated with MFIs (Siqueira et al., 2015). When their enterprises fail, borrowers are in jeopardy of defaulting on their loans and, regrettably, it appears that MFIs continue to seek repayment regardless if a micro-enterprise fails or succeeds.

Importantly, entrepreneurs are divergent from non-entrepreneurs (Arthurs and Busenitz, 2003) and cognitive differences exist between entrepreneurs and the general public (Baron, 2004; Sarasvathy et al., 1998; Zane et al., 2007). Given that all individuals from economically-advanced nations are not entrepreneurs; surely the majority of the rural poor from less-developed nations are not entrepreneurs, either. Considering the uniqueness of entrepreneurs and over 100 million borrowers have received funding from MFIs, it is improbable that each micro-financing recipient is an entrepreneur. Indeed, it is possible that a large percentage of micro-financing loans are used for purposes beyond the funding of micro-enterprises. Although in the case of Nepal, the Nepalese government through the Rural Microfinance Development Centre, places restrictions on MFIs to ensure borrowers use their micro-loans on enterprises (Srinivasan, 2007); there are instances of borrowers using their financing for means beyond starting micro-enterprises. In fact, Karim (2008) found that loan officers from MFIs encounter significant pressure to recover loans and are unable to effectively monitor how loans are used. Through their research, Shakya and Rankin (2008) found that over $70 \%$ of micro-financing borrowers used their loans for consumption. If used for consumption, micro-financing transmogrifies into subprime lending, or even, predatory lending comparable to the criminal loan sharks mentioned earlier. If predatory lending is directed toward the rural poor of underdeveloped nations, the results can be detrimental as borrowers often do not have steady incomes to sustain their basic needs let alone repay their debt. Given these issues, Shayka and Rankin (2008) argue that the high loan 
volumes and repayment rates are not indicators of success. It is believed that these figures simply conceal that certain MFIs appear to thrive off increasing cycles of debt and in many situations, micro-financing fails to achieve a level of financial sustainability for the beneficiary.

Although it has been suggested that micro-financing cannot address rural poverty successfully without educating beneficiaries (Hassan, 2002), many MFIs do not offer educational services as they are too focused on the revenue-generating aspects of the model. As mentioned, there are MFIs that promise shareholders high returns. In order to provide these returns, the MFIs minimise their costs by reducing the educational offerings to borrowers. Without the education, beneficiaries might not possess the necessary tools to manage their enterprises successfully. However, to address these issues, several MFIs have started to take a multidimensional approach to their service offerings by providing recipients with training, credit, and integrated savings accounts (Bharti, 2014). Although steps have been taken to improve the quality of MFI services, which can ensure that beneficiaries are not exploited, there remains a need for improvement. Importantly, the micro-financing model does not address poverty among the general poor; theoretically, the model can only assist entrepreneurs. Moreover, most MFIs target individuals that float around the poverty line - the institutions do not address the needs of the most destitute (Daru et al., 2005). Given this discrimination, ending the cycle of poverty becomes increasingly elusive through micro-financing initiatives. Indeed, the model might not be the most effective solution to address rural poverty. In the worst-case, micro-financing might actually be a contributor (Hassan, 2002). Therefore, an alternative model to address rural poverty by reaching those that do not have the expertise, knowledge, or the ability and desire to start their own businesses, is needed.

\section{Theoretical foundations}

Altruism is based on the belief that individuals should advance the interests of others at the expense of (or prior to) themselves. It is believed that individuals have empathetic qualities and are sympathetic toward others and, as such, they should show concern for other people (Jones and Ryan, 1997). Altruism theory dates as far back as the philosophical discourse of Confucius. The central tenets of Confucianism involve charity, altruism, love, trust, fidelity, honesty, courtesy, and benevolence (Luo, 2011; Zhu and Yao, 2008). The Confucian mentality is founded on altruism and building a system of morality in society. Confucians believe that communities flourish when individuals do not place their interests above those of others (Bailey, 2011). Similarly, in his writings on the responsibility to 'the other', Levinas (1981) contends that individuals have a duty to serve the other. The other is a metaphor for anyone and everyone. Through this philosophy, Levinas (1981) contends that the responsibilities to the other are endless, infinite, and total (Bevan and Corvellec, 2007). These responsibilities cannot be ignored or refused (Bevan and Corvellec, 2007). If needed, Levinas (1981) suggests that individuals are to give their last remaining food or clothes to the other. Importantly, this responsibility is non-reciprocal and individuals are expected to sacrifice themselves for the other. In fact, individuals are expected to be responsible for the other's life in advance of their own (Bevan and Corvellec, 2007). From the Confucian and Levinas discourse, it appears that human beings are capable of altruism and are motivated by altruistic 
behaviour. For example, in angel investing, altruism is considered to be the key driving factor behind the investment as the 'angels' wish to give back to the entrepreneurial community (Ramadani, 2012).

Conversely, it has been suggested that humans are only capable of advancing their self-interests or that individuals are naturally egoistic (Burks, 1966). Indeed, it has been suggested that even when humans act altruistically, they are doing this for selfish-related purposes (i.e., personal gratification) (Burks, 1966). In this way, Meewella and Sandhu (2012) demonstrated that social entrepreneurship is often not based on one's expression of altruism, but rather a desire for personal fulfilment. However, regardless of their intentions, there are numerous examples that demonstrate humans are capable of altruistic behaviour. Specifically, the entire charitable industry that is founded by philanthropists, the donors that support them, and the volunteers that manage them, provide evidence of altruistic behaviour in society. In his research, the Nobel Laureate, Herbert Simon, provides numerous examples of altruistic behaviour in economics. Nevertheless (with an eye on the altruism versus egoism debate), I follow the school of thought that believes humans are not only capable of altruistic behaviour, but are motivated to behave altruistically (Dawkins, 1976; Simon, 1993; Wright, 1994).

\section{A model for sustainable education}

Education is considered to be vital to the development and growth of economies (Ramadani et al., 2013). It has been shown that education typically accounts for 15 to $25 \%$ of growth in the income of employees and, as a result, education has been considered vitally important to technological innovation and economic sustainability (Ramadani et al., 2013). Given the importance, a model for sustainable education was developed, with a focus on children that are at-risk of leaving school as a result of poverty, in this research. It is believed that to end the cycle of poverty, one must focus on a generational solution by addressing child poverty (Mayer, 2002) through the development of education (Kalifeh et al., 2011). Put plainly, if poverty is addressed generationally and it is eliminated at the level of the child, it is very likely that the cycle of poverty will end with that generation as their offspring will likely have greater economic opportunities (Piperata et al., 2011).

To combat rural poverty whilst countering the disadvantages of micro-financing, the model for sustainable education is built on altruism theory and, also, the banking monetary multiplier. In the banking context, financial institutions use reserve ratios to expand and contract the supply of money. Higher reserve ratios mean lower monetary multipliers and, therefore, less creation of new checkable deposits through loans. Smaller reserve ratios mean higher monetary multipliers and, thus, more creation of new checkable deposits (McConnell and Brue, 2004). With a high reserve ratio (e.g., 50\%), the monetary multiplier would be $2(1 / 0.5)$. If a low reserve ratio is used (e.g., $5 \%)$, the monetary multiplier would be $20(1 / 0.05)$.

In the model for sustainable education, the monetary multiplier concept is used as an expansion mechanism to ensure long-term sustainability whilst minimising the negative effects on borrowers. Using the multiplier effect with a ratio of $50 \%$, the tuition of one impoverished child is paid until his or her education is complete. These beneficiaries only 'repay' their loans when they have completed their studies, gained permanent employment, and have secured financial independence. The loan is not repaid directly to 
a social enterprise; beneficiaries remunerate by paying the tuition of two impoverished children from their community. In the model, the monetary multiplier replaces the charging of interest. To ensure that the programme is fair, equitable, and sustainable, the reserve ratio should be set at no less than $50 \%$. Thus, through a $50 \%$ multiplier ratio, multiple children are lifted out of their impoverished state with an initial investment.

Similar to micro-financing, no collateral is taken from beneficiaries and there are no contracts. Beneficiaries are not obliged to repay their loans and the group borrowing concept is eliminated. As such, there is no social pressure or aggressive collection procedures. Importantly, the model for sustainable education is founded on altruism principles. Considering that the graduates of the programme have been assisted through the altruistic motivations of others, using Aristotle's virtue ethics, which emphasises the importance of moral character and virtuous behaviour, it is believed that beneficiaries will be motivated to perpetuate the initiative as they will feel that they have the duty to. This duty is further consistent with the Asian cultural norms associated with honour that was mentioned earlier ( $\mathrm{Su}$ and Littlefield, 2001). Indeed, the model for sustainable education is not only consistent with the definition of social entrepreneurship outlined earlier (Holloway, 2010), but also the definition of sustainable entrepreneurship, which "views entrepreneurship as a potentially potent tool in shifting socio-economic institutions, both private and public, toward an orientation that contributes to sustainable development [Tilley and Parrish, (2006), p. 281]”.

\subsection{World Pathfinder Children's Fund Inc. - case example}

Founded in 2009, the World Pathfinder Children's Fund (WPCF) is a non-profit corporation that operates through the model for sustainable education. The entity provides tuition to impoverished rural Nepalese children on the verge of relinquishing their education to enter the workforce (World Pathfinder Children's Fund Inc., 2014) ${ }^{1}$. In the WPCF context, the monetary multiplier functions similarly to that of the banking system. Specifically, the organisation funds a child's education and once the child graduates and commences gaining stable income through employment, the graduate provides tuition to other impoverished children from the same community. To ensure the sustainability of the organisation, the reserve ratio is set at $50 \%$.

To make certain that prospective families understand the requirements associated with receiving educational subsidisation through WPCF, the model is thoroughly explained to each prospective family. Specifically, volunteers ask if a child is willing to take a pledge to assist two other impoverished children from their village after they graduate from school and begin working. If the family agrees, WPCF funds the child's education. In most situations, the Nepalese people overwhelmingly accept the pledge as community members become empowered and engaged with alleviating their circumstances. The pledge enables the Nepalese people to remove themselves from poverty whilst the organisation perpetuates by becoming less reliant on donations. To this end, beneficiaries are receiving a 'hand up' whereby they are provided with the opportunity to surmount poverty themselves and, not necessarily, relying on a 'handout' (Ang, 2004). In this way, beneficiaries develop self-confidence as they are helping themselves and are considered jointly-responsible in improving their conditions (Ang, 2004). Therefore, if the members of the impoverished community are encouraged to seek 
their own identities and develop their own independence, they should be in an improved position to escape the cycle of poverty (Ang, 2004).

Indeed, the WPCF bestows a long-term perspective upon beneficiaries because at first, they receive aid throughout their educational tenure. Then, overtime, they experience the shift from impoverishment to financial sustainability and, in turn, see this shift in others through their aid to the next generation of beneficiaries. Although WPCF has been successful through the use of the model for sustainable education, the entity encounters several issues. Like most social enterprises, WPCF is reliant upon donations from external entities. A limitation to the model is that the charitable industry has become increasingly saturated with aggressive competition (Gaskin, 1999) and accessing stable funding can be challenging (Holloway, 2010). Not only is accessing funding an issue, negative publicity involving corruption has occurred within the charitable sector. Indeed, potential donors have been reluctant to contribute to charities as a lack of transparency exists - donors do not know how their funds will be dispersed (Gaskin, 1999). However, this issue is addressed as the second generation beneficiaries - those that are receiving support from the recent graduates - enter the programme as the monetary multiplier reduces the reliance on funding from external sources.

To further address these industry challenges, the WPCF differentiates itself from the competition in several areas. First, the organisation uses $100 \%$ of its donations directly toward providing educational subsidies to impoverished children, which can counter the transparency concerns of potential donors. Second, there are no overhead expenditures or salaries - the entity functions solely through volunteers. By relying on local volunteers, overhead expenditures are minimised. Any overhead expenditures are paid by the volunteers and founding members. However, the organisation experiences logistical issues associated with reaching the rural poor. Considering that a dearth of information technology is available in the rural areas of less-developed nations, accounting for the use of funds for each child throughout his or her academic tenure can be a daunting task. To manage the programme more effectively, an area for future research might involve developing a sophisticated system to account for the funds consumed by each child. In addition, recent graduates often migrate to urban centres to seek employment and, thus, tracking graduates to ensure two additional children are assisted, can be difficult. To address this concern, a humane system to track graduates, or alumni of the programme, could also be developed.

\subsection{Limitations to the model}

In addition to the challenges outlined in the previous section, there are two limitations to the model for sustainable education. First, the model scales very slowly as it is not based on egoistic motivations - there are no shareholders or opportunities to offer investors a return on their investment. However, by ensuring beneficiaries complete the programme successfully prior to requiring repayment, the model for sustainable education has the potential for long-term success. The traditional micro-financing model appears to be a short-term solution that might not provide the rural poor with the necessary skills to remove themselves from poverty. On the contrary, the model for sustainable education counters this concern by providing children access to the benefits of education, which can supply them with the skills needed to surmount poverty.

Second, the model could be perceived as indebting children to a social enterprise; however, as outlined earlier, it is not mandatory for beneficiaries to repay their tuition. It 
is believed that through virtuous behaviour, the beneficiaries will be motivated to assist other impoverished children. Although the first generation of recipients will be temporarily disadvantaged as they would be assisting two additional children, future generations will benefit through the initial sacrifices as the model has the potential to end the cycle of poverty. Moreover, it is worth emphasising that the multiplier ratio could be expanded or contracted to control the burden on graduates.

It is often believed that when the level of education increases in a nation, the level of poverty decreases (Chaudhry et al., 2010). Through the model for sustainable education, four of the main issues of rural poverty have been addressed. First, the model can assist in reducing the cycle of poverty. Second, the literacy rates in the rural areas of less developed nations can increase. Third, the supply of children that enter the human trafficking industry can be minimised. Finally, the model for sustainable education can address all levels of poverty, not just the 'middle-poor', which is the sole target group of many MFIs (Daru et al., 2005).

\section{Conclusions}

To address the needs of society, a bold entrepreneurial spirit is often needed. An entrepreneurial spirit ignited the micro-financing model that was developed over four decades ago. However, it has been shown that micro-financing can be detrimental if:

1 borrowers are not educated properly

2 the funds are used for other purposes beyond funding micro-enterprises.

To counter the many challenges associated with the original model, micro-financing must now be revolutionised to provide both financial and non-financial services to the impoverished (Bharti, 2014) and attain its noble objective - ending the cycle of poverty. First, better management of the beneficiaries and their use of funds could minimise the exploitation of loan recipients and ensure beneficiaries only use micro-loans to develop micro-enterprises. To ensure resources are used to fund micro-enterprises, applicants should have their enterprising idea approved prior to receiving funding. This would be similar to the process used by entrepreneurs who seek funding from financial institutions and venture capitalists. Second, interest rates should be reduced to non-profit levels (Ang, 2004), which can ensure the sustainability of the programme whilst minimising the exploitation of borrowers. Third, a more humane loan recovery process should be established. Finally, the micro-financing model should be improved to not only focus on rural entrepreneurs, but more importantly, the majority of the rural poor who, most likely, are not entrepreneurs.

Although important, micro-financing is by no means the sole solution to addressing rural poverty, providing access to education, technology, healthcare, and agricultural development are equally important (Ang, 2004). To further address rural poverty, the model for sustainable education is a useful alternative to micro-financing. It has the potential to increase literacy rates and can be used in tandem with micro-financing. Although the model for sustainable education is in the early stages of development, opportunities exist for refinement. Beyond education, the model could be used to address other social issues. For example, the model could be used to fund agricultural programmes in famine-prone areas. In this context, funds would be provided to farmers 
seeking to invest in seeds and agricultural equipment. Once farmers begin to yield crops and become profitable, the original farmers would be required to assist other farmers in their community. This cannot only address famine concerns, but also economic issues.

\section{References}

Agrawal, S. and Gugnani, R. (2014) 'Creating successful business model: lessons for social entrepreneurship', International Journal of Entrepreneurship and Innovation Management, Vol. 18, Nos. 5/6, pp.438-446.

Ahmad, S.Z. (2012) 'Microfinance for women micro and small-scale entrepreneurs in Yemen: achievements and challenges', International Journal of Entrepreneurship and Small Business, Vol. 16, No. 1, pp.102-121.

Ahmed, A. and McQuaid, R.W. (2005) 'Entrepreneurship, management, and sustainable development', World Review of Entrepreneurship, Management and Sustainable Development, Vol. 1, No. 1, pp.6-31.

Ang, M.H. (2004) 'Empowering the poor through microcredit', International Journal of Entrepreneurship and Innovation Management, Vol. 4, No. 5, pp.485-495.

Arthurs, J.D. and Busenitz, L.W. (2003) 'The boundaries and limitations of agency theory and stewardship theory in the venture capitalist/entrepreneur relationship', Entrepreneurship Theory and Practice, Vol. 28, No. 2, pp.145-162.

Bailey, A.D. (2011) 'Dialogue: the Confucian critique of rights-based business ethics. Confucianism-based rights skepticism and rights in the workplace', Business Ethics Quarterly, Vol. 21, No. 4, pp.661-677.

Baker, R. and Hinton, R. (2001) 'Approaches to children's work and rights in Nepal', The Annals of the American Academy of Political and Social Science, May, Vol. 575, No. 1, pp.176-193.

Baron, R.A. (2004) 'The cognitive perspective: a valuable tool for answering entrepreneurship's basic “why" questions', Journal of Business Venturing, Vol. 19, No. 2, pp.221-239.

Bevan, D. and Corvellec, H. (2007) 'The impossibility of corporate ethics: for a Levinasian approach to managerial ethics', Business Ethics: A European Review, Vol. 16, No. 3, pp.208-220.

Bharti, N. (2014) 'Approaches to microenterprise development: comparison of case studies from Maharashtra', International Journal of Business and Globalisation, Vol. 13 No. 4, pp.519-542.

Bhensdadia, R.R. and Dana, L.P. (2004) 'Globalisation and rural poverty', International Journal of Entrepreneurship and Innovation Management, Vol. 4, No. 5, pp.458-469.

Burks, D.M. (1966) 'Psychological egoism and the rhetorical tradition', Speech Monographs, Vol. 33, No. 4, pp.400-420.

Chakrabarty, S., Grote, U. and Luchters, G. (2011) 'Does social labelling encourage child schooling and discourage child labour in Nepal?', International Journal of Educational Development, Vol. 31, No. 5, pp.489-495.

Chaudhry, I.S., Malik, S., Hassan, A.U. and Faridi, M.Z. (2010) 'Does education alleviate poverty? Empirical evidence from Pakistan', International Research Journal of Finance and Economics, October, No. 52, pp.135-141.

Dana, L.P. (1995) 'Entrepreneurship in a remote sub-Arctic community: Nome, Alaska', Entrepreneurship: Theory and Practice, Vol. 20, No. 1, pp.57-73.

Dana, L.P. (2014) Asian Models of Entrepreneurship. From the Indian Union and Nepal to the Japanese Archipelago. Context, Policy and Practice. Asia-Pacific Business Series, Vol. 9, 2nd ed., World Scientific Publishing, Hackensack, NJ.

Daru, P. Churchill, C. and Beemsterboer, E. (2005) The Prevention of Debt Bondage with Microfinance-led Services, Social Finance Programme of the International Labour Organization. 
Dawkins, R. (1976) The Selfish Gene, Oxford University Press, Oxford, UK.

Deb, M. (2013) 'An integrated framework to serve the bottom of pyramid', International Journal of Business and Globalisation, Vol. 11, No. 2, pp.171-187.

Fujita, K. (2000) 'Credit flowing from the poor to the rich: the financial market and the role of the Grameen Bank in rural Bangladesh', The Developing Economies, Vol. 38 No. 3, pp.343-73.

Gaskin, K. (1999) 'Blurred vision: public trust in charities', International Journal of Nonprofit and Voluntary Sector Marketing, Vol. 4, No. 2, pp.163-178.

Gill, A. Biger, N. and Nagpal, V. (2011) 'Barriers to small business creations in India', International Journal of Entrepreneurship and Small Business, Vol. 13, No. 4, pp.395-410.

Gilligan, B. (2003) Child Labour in Nepal Understanding and Confronting its Determinants. An Analysis of the Determinants of Child Labour in Nepal, The Policy Environment and Response, pp.1-79, Innocenti Research Centre, Kathmandu, Nepal.

Grieco, D. and Hogarth, R.M. (2004) Excess Entry, Ambiguity Seeking, and Competence: An Experimental Investigation, Unpublished manuscript [online] http://cbdr.cmu.edu/papers/pdfs/ cdr_028.pdf (accessed 1 August 2014).

Hassan, M.K. (2002) 'The microfinance revolution and the Grameen Bank experience in Bangladesh', Financial Markets Institutions and Instruments, Vol. 11, No. 3, pp.205-264.

Holloway, R. (2010) 'NGOs: Losing the moral high ground - corruption and misrepresentation', 8th International Anti-corruption Conference, pp.1-15.

Jones, T.M. and Ryan, L.V. (1997) 'The link between ethical judgment and action in organizations', Organization Science, Vol. 8, No. 6, pp.663-680.

Kalifeh, P., Cohen-Vogel, L. and Grass, S. (2011) 'The federal role in early childhood education: evolution in the goals, governance, and policy instruments of project head start', Educational Policy, Vol. 25, No. 1, pp.36-64.

Karim, L. (2008) 'Demystifying micro-credit. The Grameen Bank, NGOs, and neoliberalism in Bangladesh', Cultural Dynamics, Vol. 20, No. 5, pp.5-29.

Kobeissi, N. and Damanpour, F. (2003) 'The diffusion of a socially responsible innovation: Grameen Bank's credit delivery system', International Journal of Entrepreneurship and Innovation Management, Vol. 3, Nos. 5/6, pp.563-585.

Levinas, E. (1981) Otherwise Than Being - or Beyond Essence, Duquesne University Press, Pittsburgh, PA.

Light, I. and Dana, L.P. (2013) 'Boundaries of social capital in entrepreneurship', Entrepreneurship Theory and Practice, January 2013, Vol. 37, No. 3, pp.603-624.

Luo, S. (2011) 'Is yi more basic than ren in the teachings of Confucius?', Journal of Chinese Philosophy, Vol. 38, No. 3, pp.427-443.

Mayer, S.E. (2002) The Influence of Parental Income on Children's Outcomes, Knowledge Management Group, Ministry of Social Development, Te Manatu Whakahiato Ora: Wellington, NZ.

McConnell, C.R. and Brue, S.L. (2004) Economics: Principles, Problems and Policies (16e), McGraw-Hill Companies, New York, NY.

Meewella, J. and Sandhu, M. (2012) 'Commercial benefits of social entrepreneurship', World Review of Entrepreneurship, Management and Sustainable Development, Vol. 8 No. 3, pp.340-358.

Piperata, B.A., Spence, J.E., Da-Gloria, P. and Hubbe, M. (2011) 'The nutrition transition in Amazonia: rapid economic change and its impact on growth and development in Ribeirinhos', American Journal of Physical Anthropology, Vol. 146, No. 1, pp.1-13.

Rajouria, A. (2008) Micro-Finance and Empowerment of Women: Evidence From Nepal, University of Hawai'i Library Doctor of Philosophy Dissertation, pp.1-180.

Ramadani, V. (2012) 'The importance of angel investors in financing. the growth of small and medium sized enterprises', International Journal of Academic Research in Business and Social Sciences, Vol. 2, No. 7, pp.1-17. 
Ramadani, V., Gerguri, S., Rexhepi, G. and Abduli, S. (2013) 'Innovation and economic development: the case of FYR of Macedonia', Journal of Balkan and Near Eastern Studies, Vol. 15, No. 3, pp.324-345.

Rexhepi, G., Kurtishi, S. and Bexheti, G. (2013) 'Corporate social responsibility (CSR) and innovation - the drivers of business growth?', Procedia - Social and Behavioral Sciences, Vol. 75, pp.532-541.

Richardson, J. (2004) 'Entrepreneurship and development in Asia', International Journal of Entrepreneurship and Innovation Management, Vol. 4, No. 5, pp.469-485.

Sankaran, M. (2005) 'Micro credit in India: an overview', World Review of Entrepreneurship, Management and Sustainable Development, Vol. 1, No. 1, pp.91-101.

Sarasvathy, D.K. Simon, H.A. and Lave, L. (1998) 'Perceiving and managing business risks: differences between entrepreneurs and bankers', Journal of Economic Behavior and Organization, Vol. 33, No. 2, pp.207-225.

Schumpeter, J.A. (1942) Capitalism, Socialism, and Democracy, Routledge, New York, NY.

Seelos, C. and Mair, J. (2005) 'Social entrepreneurship: creating new business models to serve the poor', Business Horizons, Vol. 48, No. 3, pp.241-246.

Sen, A. (1999) Development as Freedom, Random House, Inc., New York, NY.

Shakya, Y.B. and Rankin, K.N. (2008) 'The politics of subversion in development practice: an exploration of microfinance in Nepal and Vietnam', Journal of Development Studies, Vol. 44, No. 8, pp.1214-1235.

Sica, E. and Testa, G. (2009) 'Environmental sustainability and microfinancial system: what is the link?', World Review of Entrepreneurship, Management and Sustainable Development, Vol. 5, No. 3, pp.244-256.

Simon, H.A. (1993) 'Strategy and organizational evolution', Strategic Management Journal, Vol. 14, No. 2, pp.131-142.

Siqueira, A.C.O., Mariano, S.R.H., Moraes, J. and Cox, L.W. (2015) 'Institutional and interpersonal trust and entrepreneurship: insights from relationship banking and microfinance in Brazil', International Journal of Business and Globalisation, Vol. 14, No. 1, pp.58-75.

Srinivasan, S. (2007) 'Microfinance for renewable energy: financing the 'former poor', World Review of Entrepreneurship, Management and Sustainable Development, Vol. 3, No. 1, pp.79-90.

Su, C. and Littlefield, J.E. (2001) 'Entering guanxi: a business ethical dilemma in mainland China?', Journal of Business Ethics, Vol. 33, No. 3, pp.199-211.

Tata, J. and Prasad, S. (2008) 'Social capital, collaborative exchange and microenterprise performance: the role of gender', International Journal of Entrepreneurship and Small Business, Vol. 5, Nos. 3/4, pp.373-389.

Tilley, F. and Parrish, B.D. (2006) 'From poles to wholes: facilitating an integrated approach to sustainable entrepreneurship', World Review of Entrepreneurship, Management and Sustainable Development, Vol. 2, No. 4, pp.281-294.

Wheaton, E.M., Schauer, E.J. and Galli, T.V. (2010) 'Economics of human trafficking', International Migration, Vol. 48, No. 4, pp.114-142.

World Pathfinder Children's Fund Inc. (2014) Home [online] http://pathfindernepal.com/ (accessed 8 August 2014).

Wright, R. (1994) The Moral Animal: Why We are, The Way We are: The New Science of Evolutionary Psychology, Vintage Books, New York, NY.

Yunus, M., Moingeon, B. and Lehmann-Ortega, L. (2010) 'Building social business models: lessons from the Grameen experience', Long Range Planning, Vol. 43, No. 2010, pp.308-325.

Zane, L.J., DeCarolis, D.M. and DiRenzo, M.S. (2007) 'An examination of the role of opportunity cost and opportunity value in new venture creation', Frontiers of Entrepreneurship Research, Vol. 27, No. 6, pp.1-15. 
Zhu, W. and Yao, Y. (2008) 'On the value of traditional Confucian culture and the value of modern corporate social responsibility', International Journal of Business and Management, Vol. 3, No. 2, pp.58-63.

\section{Notes}

1 This research is based on an ethnographic study that commenced in 2009. With the Nepalese founder of WPCF, I have travelled extensively through the Annapurna Himalayan Range near Pokhara, Nepal to communicate with the families receiving support from WPCF. This study involved trekking through the treacherous rural terrain, visiting with the families, assessing the progress of the children, and interviewing the family members. The purpose of the visits was to assess how the children and families were functioning under the model for sustainable education. Currently, there are 63 children receiving support from WPCF. In 2012, three 'first generation' students from the same family graduated from the program. Since graduation, the students have started working full-time and, as a result, the financial situation of the family has improved, vastly. Specifically, the family has purchased property in their rural village and are in the process of converting an old house into a guest house, which can accommodate the needs of the many international visitors that travel through the area. Now that these students have started working full-time and are financially independent, they are on the brink of funding the education of two impoverished children from their village. These children would be the 'second generation' beneficiaries of the program. 